\title{
Performance of a membrane bioreactor in extreme concentrations of Biphenyl A
}

\author{
Yassine Ouarda, Mehdi Zolfaghari, Patrick Drogui, Brahima Seyhi, \\ Gerardo Buelna and Rino Dubé
}

\begin{abstract}
In this study, a submerged membrane bioreactor was used to study the effect of low and high BPA concentration on the sludge biological activity. The pilot was operated over 540 days with hydraulic retention time and solid retention time of 5.5 hours and 140 days, respectively. As hydrophobic compound, BPA highly adsorbed by activated sludge. In lower concentration biodegradation rate remained low, since BPA concentration in the sludge was lower than $0.5 \mathrm{mg} / \mathrm{g}$ TS; yet, at influent concentration up to $15 \mathrm{mg} / \mathrm{L}$, biodegradation rate was increasing, resulting in $99 \%$ of BPA removal efficiency. The result on chemical oxygen demand removal showed that BPA concentration has no effect on the heterotrophic bacteria which were responsible for the organic carbon degradation. In higher concentration, up to $16 \mathrm{mg}$ of BPA was used for each gram of sludge as a source of carbon. However, the activity autotrophic bacteria, including nitrifiers, were completely halted in the presence of $20 \mathrm{mg} / \mathrm{L}$ of BPA or more. Although nitrification was stopped after day 400th, ammonia removal remained higher than $70 \%$, due to air stripping. Assimilation by bacteria was the only removal pathway of phosphorus which resulted in average $35 \%$ of $\mathrm{P}^{-} \mathrm{PO}_{4}$ removal efficiency.

Key words | ammonia, Bisphenol A, chemical oxygen demand, membrane bioreactor, phosphorus

\author{
Yassine Ouarda \\ Mehdi Zolfaghari \\ Patrick Drogui (corresponding author) \\ Institut National de la Recherché Scientifique- Eau, \\ Terre et Environnement (INRS-ETE), \\ Université du Québec \\ 490 rue de la Couronne, Québec, QC \\ Canada \\ G1 K 9A9 \\ E-mail: patrick.drogui@ete.inrs.ca \\ Brahima Seyhi \\ Centre des technologies de l'eau, \\ 696 Avenue Sainte-Croix, Montréal, QC, \\ Canada \\ $\mathrm{H} 4 \mathrm{~L} 3 \mathrm{Y}_{2}$ \\ Gerardo Buelna \\ Rino Dubé \\ Centre de Recherché Industrielle du Québec \\ (CRIQ), \\ 333 rue Franquet, Québec, QC \\ Canada \\ G1P 4C7
}

\section{INTRODUCTION}

Emerging contaminants, especially endocrine disrupting compounds (EDCs) are in the center of attention, due to their ever increasing concentration in the environment (Seyhi et al. 2013; Zhang et al. 2016). Wastewater with high concentration of EDCs was the main source of contaminants water body. The presence of EDCs in wastewaters must be taken into account owing to their potential toxicity for humans (brain cancer, affection of immune and reproductive systems, e.g.) (Vandenberg et al. 2009) and aquatic species (feminization, toxicity to fish and invertebrates, e.g.). Bisphenol-A (BPA) is one of the most prominent EDC, extensively used for many industrial applications such as, production of polycarbonate plastics, Epoxy resins, flame retardant and PVC (Staples et al. I998; Chen et al. 2008). As the carcinogenic and mutagenic effect of BPA has been proven, The US and Canadian federal ministry of health and environment imposed strict regulation on its release into the environment (Mohapatra et al. 20Io). Due to its high production (5 million tons per year) and resistance toward biodegradation, BPA has been found in many environmental matrices around the world, especially in the effluent of wastewater treatment plants (Mohapatra et al. 20I0; Huang et al. 2012). As illustrated in Figure 1, constant introduction of BPA from landfill leachate, municipal wastewater and sewage sludge increase its concentration in surface water, sediment, and even drinking water (Staples et al. 1998; Fromme et al. 2002; Fent et al. 2003; Sharma et al. 2009; Mohapatra et al. 20I0; Huang et al. 2012).

Utilization of advanced processes, such as chemical oxidation (Dudziak \& Burdzik 20I6), membrane filtration (Chen et al. 2008; Seyhi et al. 2013; Yang et al. 2013) and adsorption (Liu et al. 2009) have been recommended for efficient removal of BPA. However, complete oxidation of BPA without production of byproduct is still challenging and requires high chemical consumption and treatment cost. Due to its specific characteristics, membrane bioreactor (MBR) seems to be a promising treatment option for wastewater treatment with high concentration of BPA. Firstly, 


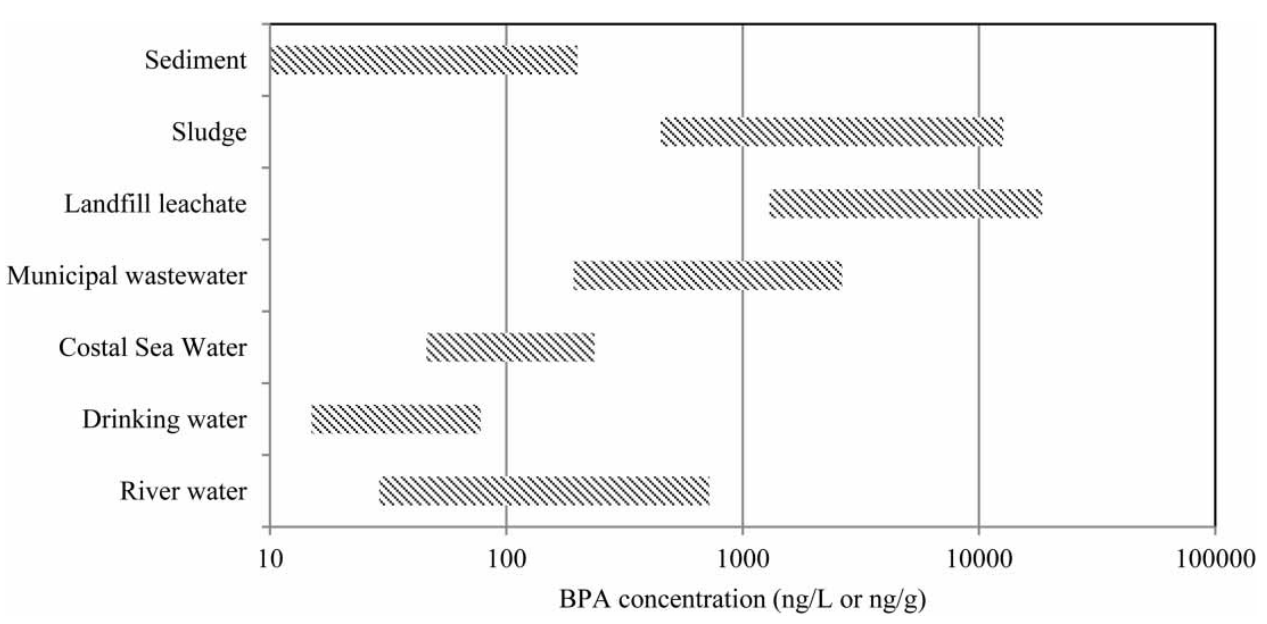

Figure 1 | average Bisphenol A concentration in different media (ng/g refers to solid matrices, while ng/L refers to aquatic matrices).

high concentration of biomass (over $15 \mathrm{~g} / \mathrm{L}$ ) (Ahmed \& Lan 20I2) increases the biosorption of hydrophobic compounds including BPA with log Kow of 3.32 (Seyhi et al. 20II). Secondly, high solid retention time (SRT) helps to develop the microorganisms strain, specialized in BPA removal through enzymatic reaction (Yang et al. 2013; Zhu \& Li 2013; Zhang et al. 20I6). In previous studies, the long-term performance of a laboratory submerged MBR system for the treatment of synthetic effluent was investigated with BPA concentration in the range of 0.6 to $1.2 \mathrm{mg} / \mathrm{L}$ (Seyhi et al. 20I3). In the present study, the performance of MBR for removal of macro-pollutants (carbon, nitrogen and phosphorus) was investigated. Synthetic wastewater used in this study was spiked by very low or very high BPA concentration. The mechanisms of removal in these two extreme conditions were investigated by analyzing BPA concentration in the sludge, influent and effluent.

\section{MATERIAL AND METHODS}

\section{Chemical}

All the organic solvents, included methanol, dichloromethane, were of analytical grade with the highest purity commercially available. Silica-based bonded C18 (Sep-Pak, $6 \mathrm{~mL}, 500 \mathrm{mg}$ ) cartridges were supplied by Waters Ltd. (Mississauga, ON, Canada). BPA, glucose, $\left(\mathrm{NH}_{4}\right)_{2} \mathrm{SO}_{4}, \mathrm{KH}_{2} \mathrm{PO}_{4}$, and the deuterated bisphenol A (BPA-d16), used as internal standard, were purchased from Sigma-Aldrich Canada Ltd. (Oakville, ON, Canada). Stock solutions of BPA were prepared in methanol at $2,000 \mathrm{mg} / \mathrm{L}$ and kept at $4{ }^{\circ} \mathrm{C}$.

\section{MBR setup}

The study was conducted at a laboratory scale submerged MBR. The pilot was composed of $6 \mathrm{~L}$ biological reactor equipped with hollow-fiber membrane (ZW-1, Zenon Environmental Inc., Canada) with pore diameter of $40 \mathrm{~nm}$ and $0.047 \mathrm{~m}^{2}$ of total filtering surface area, assembled vertically. Filtration and feeding of pilot was achieved by two peristaltic pumps. For controlling the fouling of membrane, the pump was filtrating for 5 min with 30 seconds of pause. Whenever the transmembrane pressure was increased more than $-40 \mathrm{KPa}, 30$ second of backwash was carried out. By increasing the transmembrane pressure more than $-69 \mathrm{KPa}$ (the maximum limit of vacuum pressure), the chemical wash was performed on the membrane. Firstly, the sludge cake was removed by tap water, following by circulation of $1,000 \mathrm{mg} / \mathrm{L}$ of $\mathrm{NaClO}$ for $2 \mathrm{~h}$ to eliminate biofouling. In order to remove inorganic compound, citric acid solution with concentration of $3.0 \mathrm{~g} / \mathrm{L}$ was also used for $30 \mathrm{~min}$. Air was supplied through an extended aeration tube located inside the aeration basin and membrane module.

\section{Experimental design and operation}

The MBR was inoculated with sludge taken from Quebec City municipal wastewater treatment plant. For start-up, it was feed by synthetic wastewater with glucose and BPA as the carbon source. The mineral composition of the synthetic effluent was made, in order to provide the best environment for the growth of microorganism. As indicated in previous studies (Seyhi et al. 2012), C/N/P ratio was kept at around 
$100 / 5 / 2$ by $\mathrm{C}_{6} \mathrm{H}_{12} \mathrm{O}_{6} /\left(\mathrm{NH}_{4}\right)_{2} \mathrm{SO}_{4} / \mathrm{KH}_{2} \mathrm{PO}_{4}$. During startup which took almost 40 days, desirable concentration of sludge was developed ( $14 \mathrm{~g} / \mathrm{L}$ of total suspended solid), resulting in steady carbon and nitrogen removal. MBR operation was carried out in two main phases. During the first period (A), the concentration of BPA in the synthetic solutions was increasing from 0.050 to $0.400 \mu \mathrm{g} / \mathrm{L}$ and finally $20 \mu \mathrm{g} / \mathrm{L}$ in the period of 200 days. In the second period (B), the performance of MBR was investigated in higher BPA concentration by gradual increase in concentration from $1,000 \mu \mathrm{g} / \mathrm{L}$ to $40,000 \mu \mathrm{g} / \mathrm{L}$. During startup and operating period, hydraulic retention time (HRT) and SRT were $5.5 \mathrm{~h}$ and 140 days, respectively; while, temperature and $\mathrm{pH}$ were maintained around $20 \pm 2{ }^{\circ} \mathrm{C}$ and $7 \pm 1$, respectively.

\section{Analytical methods}

Twice per week, samples were collected at the inlet, outlet and mixed liquor for the analysis of total suspended solid (TSS), total volatile suspended solid (TVSS), chemical oxygen demand (COD), ammonium $\left(\mathrm{N}-\mathrm{NH}_{4}\right)$, nitrate $\left(\mathrm{N}-\mathrm{NO}_{2}\right)$, nitrate $\left(\mathrm{N}-\mathrm{NO}_{3}\right)$, orthophosphate $\left(\mathrm{P}-\mathrm{PO}_{4}\right), \mathrm{pH}$, and BPA. All parameters were determined in conformity with standards methods. COD was measured by colorimetric method in the presence of potassium dichromate and the absorbance was measured at $600 \mathrm{~nm}$ using a UV spectrometer (Cary 50, Varian Canada Inc., Mississauga, ON, Canada) according to MA-315-DCO 1.0 method, proposed by CEAEQ. TSS measurement was conducted by centrifugation of $100 \mathrm{~mL}$ of sample from sludge mixed liquor at $8,000 \mathrm{rpm}$ for $20 \mathrm{~min}$ at $4{ }^{\circ} \mathrm{C}$. The pellet was kept for drying at $105^{\circ} \mathrm{C}$ for $24 \mathrm{~h}$. Subsequently, TVSS was measured by burning the dried pllet at $550{ }^{\circ} \mathrm{C}$ for $30 \mathrm{~min}$ according to MA-104-S.S.1.1 method. Ammonia $\left(\mathrm{NH}_{3}-\mathrm{N}\right)$ and phosphorus $\left(\mathrm{PO}_{4}-\mathrm{P}\right)$ were analyzed simultaneously by QuikChem LACHAT Instrument, based on 10-107-06-2-B and 10-115-01-1-B analytical method.

Solid Phase Extraction (SPE) was used for BPA extraction from solid sample using Visiprep system on C-18 cartridges (Seyhi et al. 20I3). The samples were filtered through glass fiber membrane (Whatman GF-C, porosity: $0.7 \mu \mathrm{m}$ ) and the retained particles were rinsed with $0.5 \mathrm{ml}$ of methanol. Prior to sample loading, the SPE cartridges were pre-conditioned with $13 \mathrm{ml}$ of methanol and $13 \mathrm{~mL}$ of ultrapure water. Later on, the cartridges were rinsed 12 times with $8 \mathrm{~mL}$ of ultrapure water to remove impurities having fewer interactions with the adsorbent. The cartridges were dried by a vacuum pump. Elution was performed twice with $5 \mathrm{~mL}$ of methanol/dichloromethane (9: 1, v/v) during 5 minutes. The extracts were evaporated under nitrogen flux at $40^{\circ} \mathrm{C}$ and then resuspended with $1 \mathrm{~mL}$ methanol. Liquid chromatography in a reversed-phase hypersil Gold column equipped with mass spectrophotometer was used for the BPA analysis (LC-MS). An isocratic flow of $0.2 \mathrm{~mL} / \mathrm{min}$ of a water/methanol $(5: 95, \mathrm{v} / \mathrm{v})$ was used at room temperature for elution. Detection was carried out in a MS system using an electrospray interface in negative ionization mode with detection limit to $0.020 \mu \mathrm{g} / \mathrm{L}$.

\section{RESULTS AND DISCUSSION}

\section{COD removal}

The performance of MBR in terms of COD reduction was monitored simultaneously with BPA. During the first monitoring period that lasted for about 200 days (Figure 2), COD concentration at the inlet had fluctuated between 710 and $1,170 \mathrm{mg} / \mathrm{L}$, with an average value of $940 \mathrm{mg} / \mathrm{L}$. As highly biodegradable glucose was used as the source of carbon, the residual COD concentration in the treated effluent was only 5 and $37 \mathrm{mg} / \mathrm{L}$ (removal efficiency of $98 \pm 2 \%$ ). Like reported in literature, presence of high concentration of heterotrophic bacteria in aeration basin results in biological oxygen demand removal efficiency higher than 95\% independent of the operating condition (Ahmed \& Lan 20I2; Seyhi et al. 20I3; Zhang et al. 2016). The relatively low concentrations of BPA $(0.4$ and $20 \mu \mathrm{g} / \mathrm{L})$ did not affect the ability of microorganisms to degrade the organic matter. However, increase in BPA concentration up to 10,000 $\mu \mathrm{g} / \mathrm{L}$ during the second period slightly increased the effluent COD concentration. During 350 days of monitoring period, influent COD concentration fluctuated between 741 and $1,241 \mathrm{mg} / \mathrm{L}$. Presence of BPA byproducts in the effluent decreased the average of COD removal efficiency; yet, it was still higher than 96\% (Figure 2). Increase in BPA concentration up to $40,000 \mu \mathrm{g} / \mathrm{L}$ destabilized MBR operating performance, increasing the COD of effluent between 444th to 490th days. Three reasons might explain this unstable condition: firstly, adsorption of extra BPA could be toxic to microorganism, caused their lysis and increase of extracellular polymer in the effluent; secondly, adopted microorganism adsorbed BPA as source of carbon instead of glucose; and finally, high concentration of BPA biodegradation byproduct release into aeration basin, increased the COD concentration in the effluent (Seyhi et al. 20I2). 


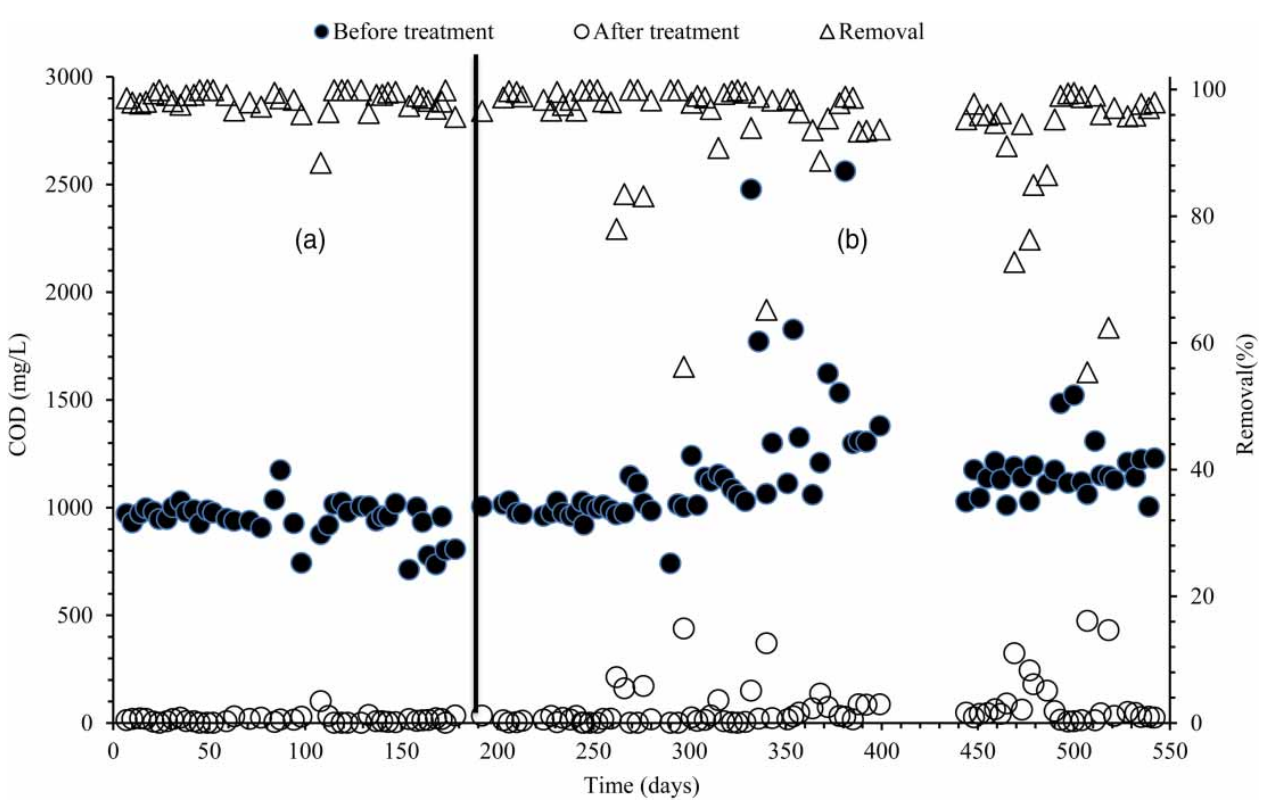

Figure 2 | Evolution of COD concentration before and after treatment (BPA initial concentration $(\mu \mathrm{g} / \mathrm{L})(\mathrm{a})=0.4-20,(\mathrm{~b})=1,000-40,000 ; \mathrm{COD}$ initial concentration $=1,000 \mathrm{mg} / \mathrm{L} ; \mathrm{HRT}=5.5 \mathrm{~h}$; $\mathrm{SRT}=140$ days)

\section{$\mathrm{N}-\mathrm{NH}_{4}$ and $\mathrm{P}^{-} \mathrm{PO}_{4}$ removal}

The removal performance of inorganic pollutants included nitrogen and phosphors were also monitored to have an idea of reactor stability. The initial ammonium concentration $\left(\mathrm{N}-\mathrm{NH}_{4}\right)$ was fluctuated between 22 and $82 \mathrm{mg} / \mathrm{L}$, with the average concentration of $58 \mathrm{mg} / \mathrm{L}$. In aerobic condition, autotrophic ammonia-oxidizing bacteria (AOB) transform $\mathrm{NH}_{4}^{+}$into $\mathrm{NO}_{2}^{-}$by means of $\mathrm{HCO}_{3}^{-}$, followed by nitrite-oxidizing bacteria (NOB) that oxidize toxic nitrite ions into the nitrate by carbonate ions (nitrification). As the nitrogen was assimilated or used to produce energy by nitrifier bacteria, the biological reaction was very complicated. Based on experimental consumption of alkalinity and oxygen, the following reaction is the overall biological nitrification (Henze et al. 200I).

$$
\begin{aligned}
& \mathrm{NH}_{4}^{+}+1.98 \mathrm{HCO}_{3}^{-}+1.83 \mathrm{O}_{2} \\
& \quad \rightarrow 0.021 \mathrm{C}_{5} \mathrm{H}_{7} \mathrm{NO}_{2}+0.98 \mathrm{NO}_{3}^{-}+2.92 \mathrm{H}_{2} \mathrm{O}+1.88 \mathrm{CO}_{2}
\end{aligned}
$$

As shown in Equation (1), approximately $14 \mathrm{~g}$ of total alkalinity and $4.2 \mathrm{~g}$ of oxygen was required for total nitrification of $1 \mathrm{gN}-\mathrm{NH}_{4}$ of ammonia. Since both AOB and NOB have biological half-life more than 10 days, it takes more than a month for development of nitrifier culture and start of nitrification process (Ahmed \& Lan 20I2); therefore during the first 40 days of operation, no nitrate was detected in the effluent and ammonia removal efficiency was lower than $18 \%$. Air stripping is the second way of nitrogen removal. In alkaline $\mathrm{pH}$ of aeration basin, almost $5 \%$ of ammonium transformed into the dissolved ammonia (Equation (2)).

$\mathrm{NH}_{4}^{+}+\mathrm{H}_{2} \mathrm{O} \leftrightarrow \mathrm{NH}_{3}+\mathrm{OH}^{-}$

Intense aeration in MBR, gradually stripped the dissolve $\mathrm{NH}_{3}$, leading to unbalancing the Equation (2) and production of more dissolved ammonia; hence, even more than $20 \%$ of ammonia removal was observed in the absence of nitrifier bacteria. MBR with high SRT provides exceptional condition for maximum development of nitrifier; along with high kinetic constant of biological nitrification, complete ammonia oxidation was expected for different organic load rate and sludge retention time higher than 30 days (Zolfaghari et al. 20I5). After treatment, the residual concentrations of $\mathrm{N}-\mathrm{NH}_{4}$ in the treated water fluctuated between 0.1 and $17 \mathrm{mg} / \mathrm{L}$, with average residual concentration of $3 \mathrm{mg} / \mathrm{L}$, corresponding to $94 \pm 4 \%$ of ammonia removal efficiency (Figure 3). Low concentration of BPA has no effect on the performance of nitrification, as autotrophic bacteria use carbonate and bicarbonate as a source of carbon. Yet, increasing the BPA concentration more than $40 \mathrm{mg} / \mathrm{L}$ after day 400 , dramatically decreased 


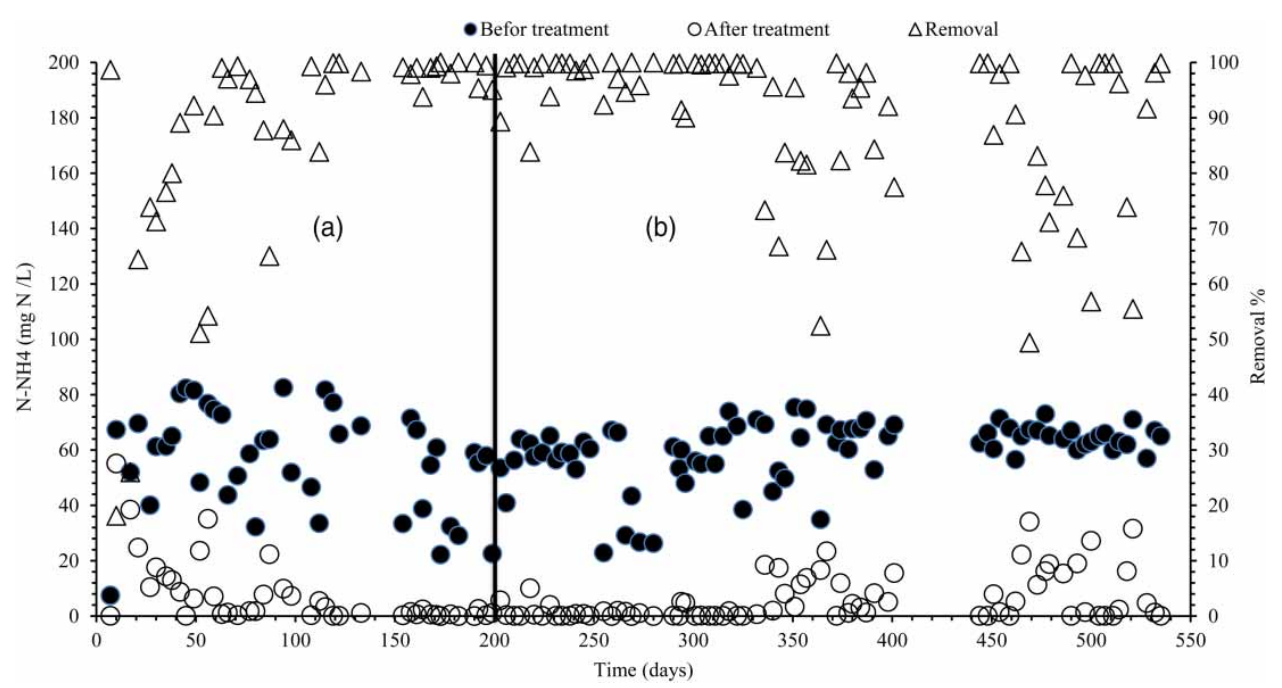

Figure 3 Evolution of influent and effluent concentration of $\mathrm{N}^{-\mathrm{NH}_{4}}$ (BPA initial concentration $(\mu \mathrm{g} / \mathrm{L})(\mathrm{a})=0.4-20,(\mathrm{~b})=1,000-40,000 ; \mathrm{COD}$ initial concentration $=1,000 \mathrm{mg} / \mathrm{L} ; \mathrm{HRT}=5.5 \mathrm{~h}$; $\mathrm{SRT}=140$ days).

the nitrifier. Absence of nitrate in the effluent indicated the complete halt of biological nitrification (Figure 4). Nitrifiying bacteria are extremely sensitive toward low concentration of oxygen and high concentration of toxic compounds. Long term exposure of $40 \mathrm{mg} / \mathrm{L}$ of BPA could change the quality and quantity of nitrosomonas and nitrobacter in the aeration basin (Zielińska et al. 20I4). In the absence of anoxic process for transformation of nitrate into the nitrogen gas (Henze et al. 200I), air stripping of ammonia is the only removal pathway of total nitrogen removal in period $\mathrm{B}$, which remained below $15 \%$ during operating period.
Unlike ammonia, phosphorus removal requires the combination of anaerobic and aerobic process for its efficient removal. Phosphorus uptake for new cell synthesis was the only removal pathway (6 $\mathrm{mg} \mathrm{P}$ for each gram of sludge) (Zolfaghari et al. 20I5). For the MBR with SRT of 140 days, the average of $35 \%$ of phosphorus was assimilated by the sludge, which later withdrew from the aeration basin. During the monitoring period, orthophosphate $\left(\mathrm{P}^{-} \mathrm{PO}_{4}\right)$ concentrations in the feeding solution have fluctuated between 11 and $39 \mathrm{mg} / \mathrm{L}$. After treatment, the residual concentration of phosphorus was between 5 and $24 \mathrm{mg} / \mathrm{L}$, indicated $31 \pm$ $16 \%$ of $\mathrm{PO}_{4}$ removal efficiency (Figure 5). It is worth

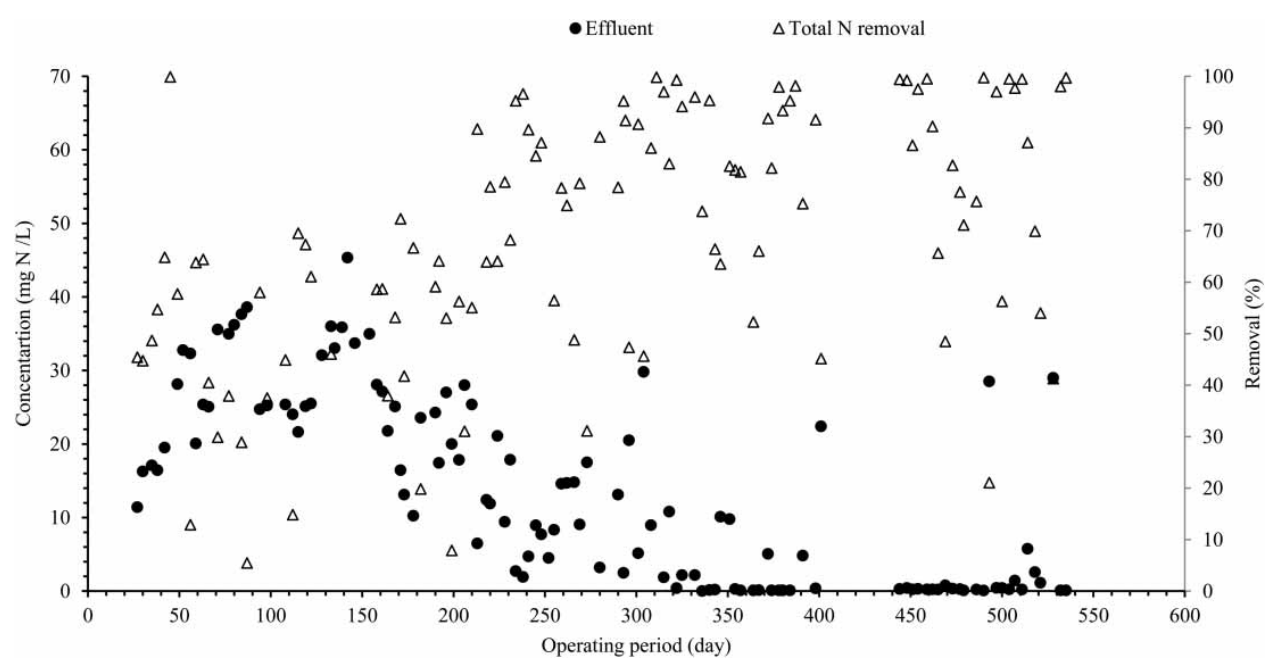

Figure 4 Evolution of $\mathrm{N}-\mathrm{NO}_{3}$ concentration in the effluent of MBR (BPA initial concentration $(\mu \mathrm{g} / \mathrm{L})(\mathrm{A})=0.4-20,(\mathrm{~B})=1,000-40,000 ; \mathrm{COD}$ initial concentration $=1,000 \mathrm{mg} / \mathrm{L} ; \mathrm{HRT}=5.5 \mathrm{~h}$; $\mathrm{SRT}=140$ days). 


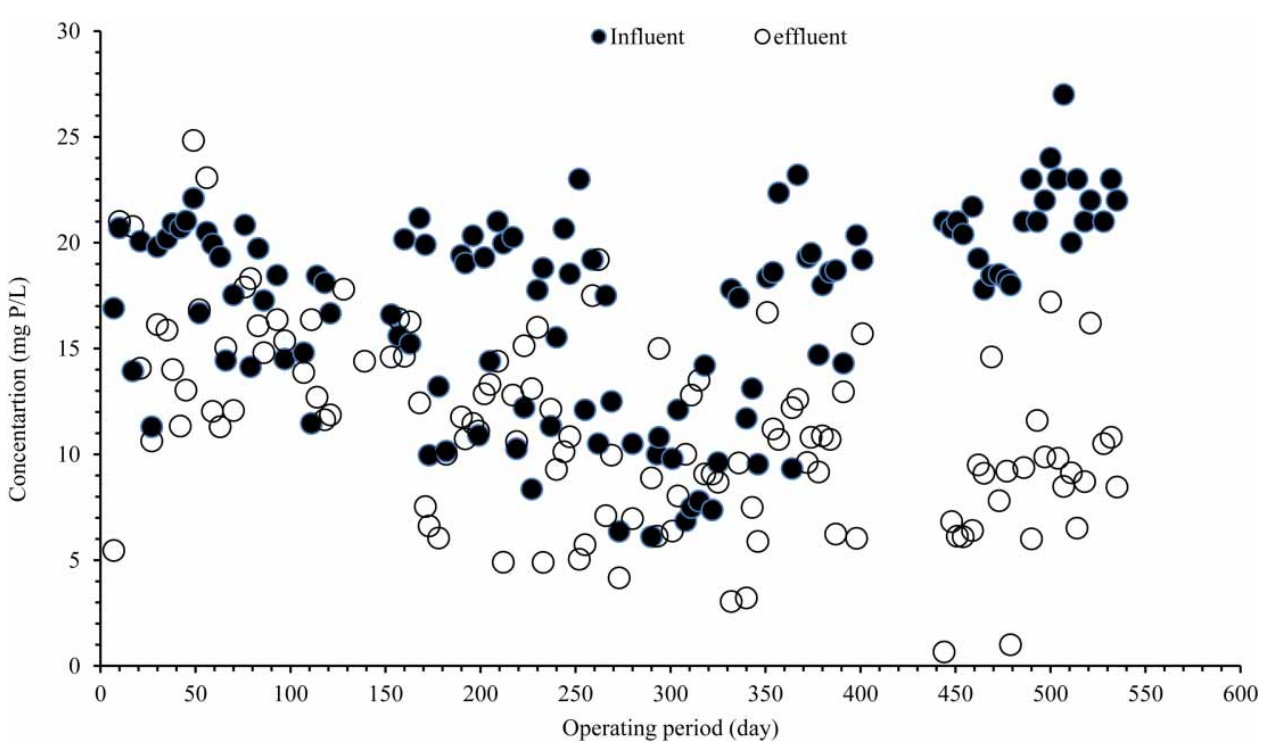

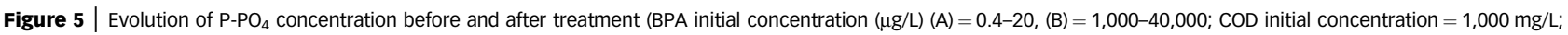
$\mathrm{HRT}=5.5 \mathrm{~h} ; \mathrm{SRT}=140$ days).

mentioning that the phosphorus concentration in the effluent was highly fluctuated, due to sudden release of soluble microbial product into the effluent (Seyhi et al. 2012). Previous study on aerobic MBR had also reported similar results with low biological phosphorus reduction rates $(47 \%$ - $70 \%)$ (Vera et al. 1997; Battistoni et al. 2006; Seyhi 2012).

\section{Performance of MBR for low BPA concentration}

As indicated in previous studies, HRT has no effect on BPA removal efficiency in the MBR; however, MBR performance was enhanced in higher SRT (Zhu \& Li 20I3; Zielińska et al. 20I4). In this study, therefore, HRT was remaining constant during operation period; while, SRT was kept as high as possible. In the first period of MBR, the concentration of BPA remained in the range of municipal wastewater and BPA removal efficiency was evaluated accordingly. During the first 70 days of operation (from day 40th to 110th), MBR was fed by a synthetic solution with the average BPA concentration of $0.400 \mu \mathrm{g} / \mathrm{L}$. BPA influent concentration in MBR was varied between $0.240-0.480 \mu \mathrm{g} / \mathrm{L}$. As shown in Figure 6, BPA residual concentration was relatively near to or below $0.02 \mu \mathrm{g} / \mathrm{L}$ with the average removal efficiency of $90 \%$. From day 130th to day 190th, the concentration of BPA was then increased to $20 \mu \mathrm{g} / \mathrm{L}$. In the vast majority of treated water samples, the residual BPA concentration was remained below $1 \mu \mathrm{g} / \mathrm{L}$. The highest residual concentration was $10.4 \mu \mathrm{g} / \mathrm{L}$, corresponding to a removal rate of
$89.5 \% \pm 12 \%$. The BPA concentration in the sludge was estimated around $480 \mu \mathrm{g} / \mathrm{g}$ dry sludge. According to Figure 7, BPA mass balance showed that almost half of $0.72 \mathrm{mg}$ of BPA was degraded in the sludge per day. Biosorption was responsible for the remaining $40 \%$ of BPA removal. It is worth mentioning that loss of BPA by evaporation could be ignored, because of its low volatility (vapor pressure of $4 \times 10^{-8} \mathrm{mmHg}$ at $25^{\circ} \mathrm{C}$ and Henry's constant of $10^{-5} \mathrm{~Pa} \cdot \mathrm{m}^{-3} \cdot \mathrm{mol}^{-1}$ ) (Chen et al. 2008). Furthermore, the size of BPA was much smaller than $40 \mathrm{~nm}$ of ultrafiltration pore size; therefore, membrane retention has no effect on BPA removal pathway (Zhu \& Li 20I3).

\section{Performance of MBR for high BPA concentration}

From day 200th to day 550th, COD concentration remained at $1,000 \mathrm{mg} / \mathrm{L}$; while, the BPA concentration was gradually increased from 1 to $40 \mathrm{mg} / \mathrm{L}$ in nine stages. As $1 \mathrm{mg} / \mathrm{L}$ of BPA was responsible for almost $2.5 \mathrm{mg} / \mathrm{L}$ of COD, glucose concentration was decreasing $10 \%$ in the presence of $40 \mathrm{mg} / \mathrm{L}$ of BPA. The increase in BPA concentration was affected once a steady state was reached (e.g. stability of BPA removal in MBR). After increasing BPA concentration in each stage, the performance of MBR was dramatically decreased (Figure 8); yet BPA removal efficiency was recovered in the period of two weeks to reach a rate of $97 \%$ or more. Indeed, increasing the initial concentration of BPA make the biomass in a state of stress, due to the toxic character of BPA. The results obtained in this study indicated 


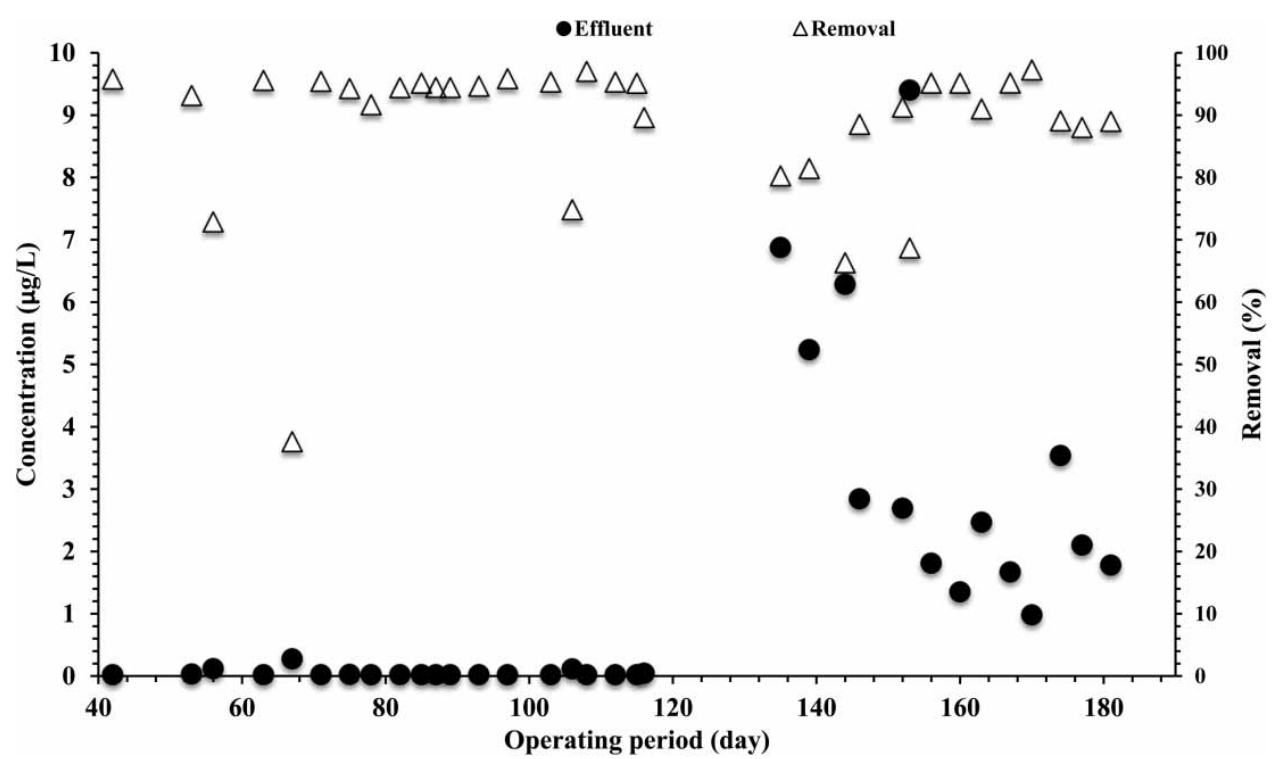

Figure 6 | Evolution of Bisphenol A concentration in the first period of operation (BPA initial concentration =0.4-20 $\mu \mathrm{g} / \mathrm{L} ; \mathrm{COD}$ initial concentration =1,000 mg/L; HRT=5.5 h; SRT=140 days).
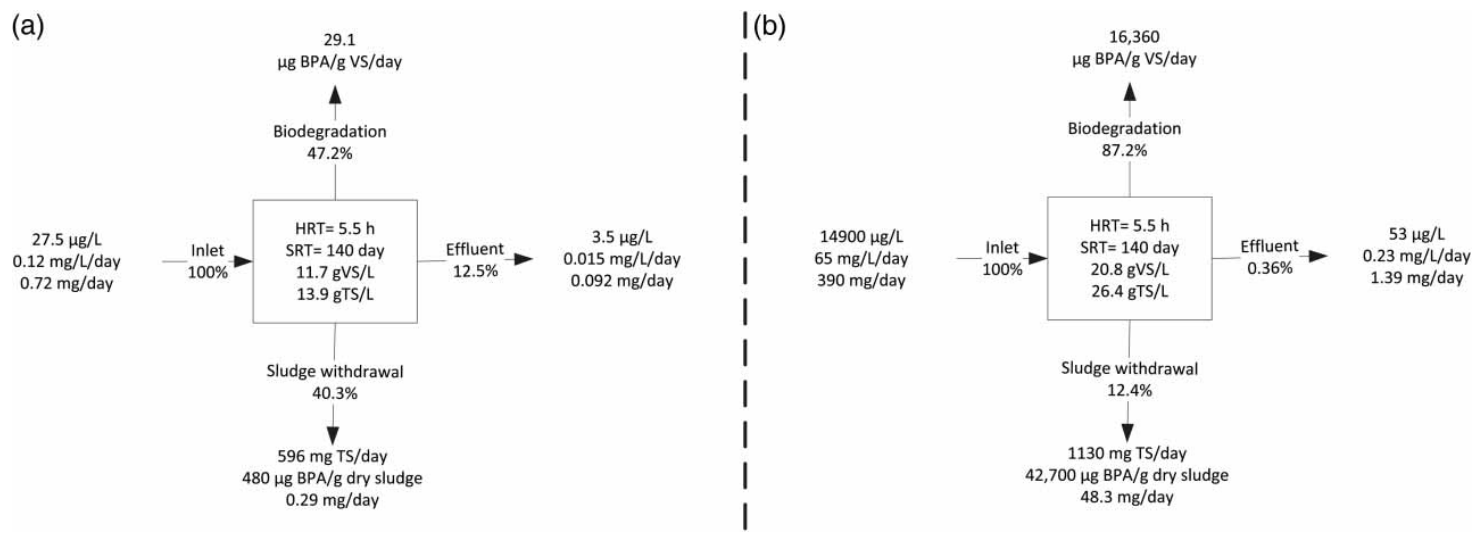

Figure 7 | Bisphenol A mass balance in the (a) 70th day and (b) 251th day.

that after the adaptation period, MBR treated effectively an effluent with initial BPA concentrations up to $40,100 \mu \mathrm{g} / \mathrm{L}$ (Figure 8). BPA mass balance study for high influent concentration showed that the rate of biodegradation was rapidly increasing up to $16 \mathrm{mg} / \mathrm{g} /$ day, resulting in $87 \%$ of BPA removal by biodegradation. As also reported in literature (Chen et al. 2008), development of specialized bacteria for BPA removal in aeration basin increased the portion of biodegradation ratio for total removal. As these bacteria retained by the membrane, their concentration is continuously increased, resulting in high BPA removal efficiency in higher concentration of BPA. In higher BPA concentration, only adopted microorganism could be survived, resulting in 560 times increase in biodegradation rate.
Enzymatic reaction could be also responsible for high biodegradation rate of BPA. It should be mentioned that high BPA removal efficiency in this stage did not indicate its complete removal. The residual byproducts of BPA biodegradation might be resistance toward further biodegradation and could be the main reason for increase in residual COD in the effluent of MBR.

\section{CONCLUSION}

This study demonstrated the effect of extreme BPA concentration on the performance of a MBR. Due to its hydrophobic characteristic, BPA was adsorbed by high 


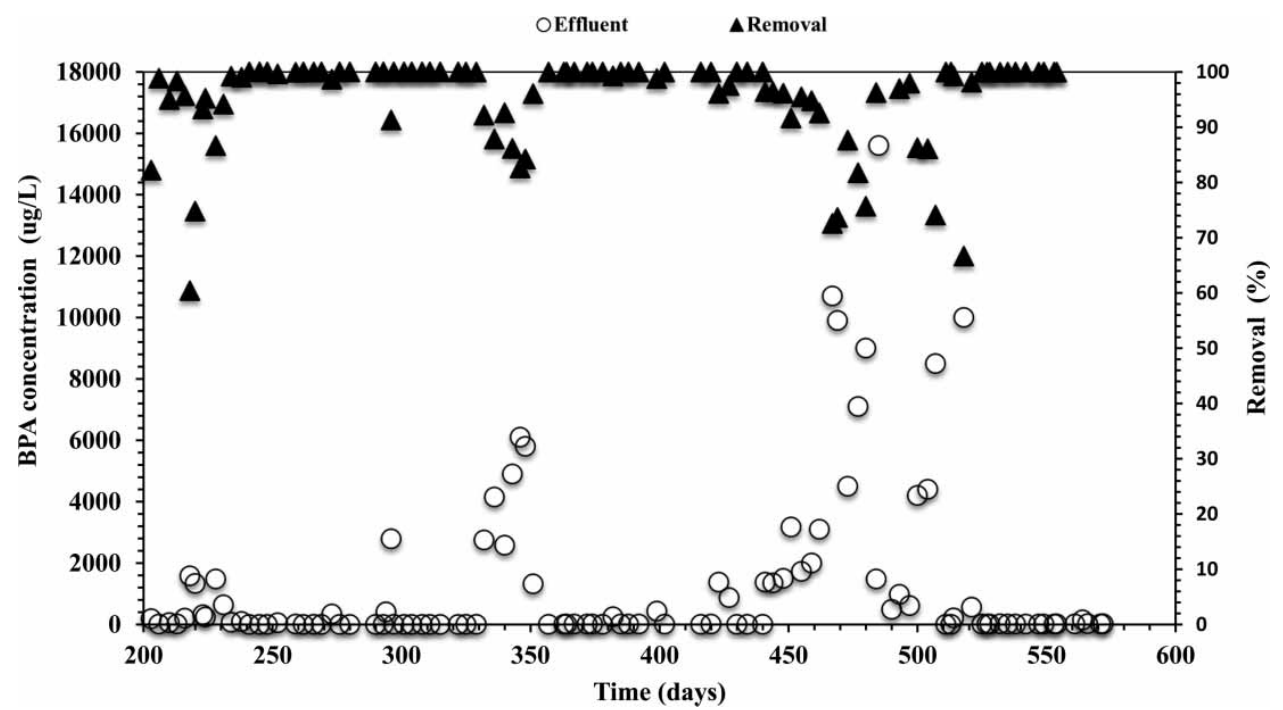

Figure 8 Evolution of Bisphenol A concentration in the second period of operation (BPA initial concentration $=1,000-40,000 \mu \mathrm{g} / \mathrm{L} ; \mathrm{COD}$ initial concentration $=1,000 \mathrm{mg} / \mathrm{L} ; \mathrm{HRT}=5.5 \mathrm{~h}$; $\mathrm{SRT}=140$ days)

concentration of activated sludge (11-20 $\mathrm{g} \mathrm{VS} / \mathrm{L})$ present in the aeration basin, resulted in average BPA removal efficiency more than 90\%. In low concentration, BPA mainly accumulated within the sludge without degradation. As its concentration raised more than $1 \mathrm{mg} / \mathrm{L}$ in influent, the biodegradation was increasing up to $16 \mathrm{mg} / \mathrm{g} \mathrm{VS} /$ day responsible for $87 \%$ of total BPA removal efficiency. Development of specialized microorganisms for degradation of BPA or triggering enzymatic reaction dramatically increased the biodegradation rate. Despite changing in BPA concentration, heterotrophic bacteria showed high COD removal efficiency (more than 95\%); yet, the performance of nitrifying bacteria were significantly reduced under BPA concentration higher than $25 \mathrm{mg} / \mathrm{L}$. Nitrogen mass balance results revealed that biological nitrification was completely stopped after day 400th. In the absence of nitrification, air stripping is responsible for $70 \%$ of ammonia removal. As $6 \mathrm{mg}$ of phosphorus was require for the production of a gram of sludge, the average of $37 \%$ of phosphate was removed from the influent.

\section{REFERENCES}

Ahmed, F. N. \& Lan, C. Q. 20I2 Treatment of landfill leachate using membrane bioreactors: a review. Desalination 287, 41-54.

Battistoni, P., Fatone, F., Bolzonella, D. \& Pavan, P. 2006 Full scale application of the coupled alternate cycles-membrane bioreactor (AC-MBR) process for wastewater reclamation and reuse. Water Practice and Technology 1 (4), wpt2006077.
Chen, J., Huang, X. \& Lee, D. 2008 Bisphenol A removal by a membrane bioreactor. Process Biochemistry 43 (4), 451-456.

Dudziak, M. \& Burdzik, E. 2016 Oxidation of bisphenol A from simulated and real urban wastewater effluents by UV, O3 and UV/O3. Desalination and Water Treatment 57 (3), 1075-1083.

Fent, G., Hein, W. J., Moendel, M. J. \& Kubiak, R. 2003 Fate of 14C-bisphenol A in soils. Chemosphere 51 (8), 735-746.

Fromme, H., Küchler, T., Otto, T., Pilz, K., Müller, J. \& Wenzel, A. 2002 Occurrence of phthalates and bisphenol $\mathrm{A}$ and $\mathrm{F}$ in the environment. Water Research 36 (6), 1429-1438.

Henze, M., Harremoes, P., la Cour Jansen, J. \& Arvin, E. 200I Wastewater Treatment: Biological and Chemical Processes. Springer Science \& Business Media.

Huang, Y., Wong, C., Zheng, J., Bouwman, H., Barra, R., Wahlström, B., Neretin, L. \& Wong, M. 2012 Bisphenol A (BPA) in China: a review of sources, environmental levels, and potential human health impacts. Environment International 42, 91-99.

Liu, G., Ma, J., Li, X. \& Qin, Q. 2009 Adsorption of bisphenol A from aqueous solution onto activated carbons with different modification treatments. Journal of Hazardous Materials 164 (2), 1275-1280.

Mohapatra, D., Brar, S., Tyagi, R. \& Surampalli, R. 20Io Physicochemical pre-treatment and biotransformation of wastewater and wastewater Sludge-Fate of bisphenol A. Chemosphere 78 (8), 923-941.

Seyhi, B. 2012 Contribution à l'étude de l'applicabilité des biotraitements à membrane dans le traitement des eaux usées contaminées par le bisphénol-A et autres polluants organiques et inorganiques. Université du Québec.

Seyhi, B., Drogui, P., Buelna, G. \& Blais, J. F. 20I Modeling of sorption of bisphenol A in sludge obtained from a membrane bioreactor process. Chemical Engineering Journal 172 (1), 61-67. 
Seyhi, B., Drogui, P., Buelna, G. \& Blais, J. F. 2012 Removal of bisphenol-A from spiked synthetic effluents using an immersed membrane activated sludge process. Separation and Purification Technology 87, 101-109.

Seyhi, B., Drogui, P., Buelna, G., Azaïs, A. \& Heran, M. 2013 Contribution of a submerged membrane bioreactor in the treatment of synthetic effluent contaminated by Bisphenol-A: mechanism of BPA removal and membrane fouling. Environmental Pollution 180, 229-235.

Sharma, V. K., Anquandah, G. A., Yngard, R. A., Kim, H., Fekete, J., Bouzek, K., Ray, A. K. \& Golovko, D. 2009 Nonylphenol, octylphenol, and bisphenol-A in the aquatic environment: a review on occurrence, fate, and treatment. Journal of Environmental Science and Health Part A 44 (5), 423-442.

Staples, C. A., Dome, P. B., Klecka, G. M., Oblock, S. T. \& Harris, L. R. 1998 A review of the environmental fate, effects, and exposures of bisphenol A. Chemosphere 36 (10), 2149-2173.

Vandenberg, L. N., Maffini, M. V., Sonnenschein, C., Rubin, B. S. \& Soto, A. M. 2009 Bisphenol-A and the great divide: a review of controversies in the field of endocrine disruption. Endocrine Reviews 30 (1), 75-95.

Vera, L., Villarroel-Lopez, R., Delgado, S. \& Elmaleh, S. 1997 Cross-flow microfiltration of biologically treated wastewater. Desalination 114 (1), 65-75.
Yang, S., Hai, F. I., Nghiem, L. D., Nguyen, L. N., Roddick, F. \& Price, W. E. 2013 Removal of bisphenol A and diclofenac by a novel fungal membrane bioreactor operated under nonsterile conditions. International Biodeterioration \& Biodegradation 85, 483-490.

Zhang, H., Wang, Y., Wang, J. \& He, Y. 2016 Mechanism of bisphenol A removal by a submerged membrane bioreactor in the treatment of synthetic municipal sewage: staged analyses. Desalination and Water Treatment 57 (26), 12364-12374.

Zhu, H. \& Li, W. 2013 Bisphenol A removal from synthetic municipal wastewater by a bioreactor coupled with either a forward osmotic membrane or a microfiltration membrane unit. Frontiers of Environmental Science \& Engineering 7 (2), 294-300.

Zielińska, M., Cydzik-Kwiatkowska, A., Bernat, K., Bułkowska, K. \& Wojnowska-Baryła, I. 20I4 Removal of bisphenol A (BPA) in a nitrifying system with immobilized biomass. Bioresource Technology 171, 305-313.

Zolfaghari, M., Drogui, P., Seyhi, B., Brar, S. K., Buelna, G., Dubé, R. \& Klai, N. 2015 Investigation on removal pathways of Di 2 ethyl hexyl phthalate from synthetic municipal wastewater using a submerged membrane bioreactor. Journal of Environmental Sciences 37, 37-50.

First received 11 April 2017; accepted in revised form 1 January 2018. Available online 22 January 2018 